\title{
PENGARUH OLAH TANAH DAN PEMUPUKAN NITROGEN JANGKA PANJANG TERHADAP BOBOT ISI, RUANG PORI TOTAL, KEKERASAN TANAH DAN PRODUKSI TANAMAN JAGUNG (Zea mays L.) DI LAHAN POLINELA BANDAR LAMPUNG
}

\author{
Refki Kurniawan Khair, Muhajir Utomo, Afandi \& Irwan Sukri Banuwa \\ Jurusan Agroteknologi Fakultas Pertanian Universitas Lampung \\ Jl. Prof Soemantri Brodjonegoro No. 1 Bandar Lampung 35143 \\ Email: dongahrefki@gmail.com
}

\begin{abstract}
ABSTRAK
Olah tanah konservasi (olah tanah minimum dan tanpa olah tanah) menjadi alternatif penyiapan lahan yang dilaporkan dapat mempertahankan produktivitas tanah tetap tinggi. Salah satu faktor penting yang menentukan keberhasilan olah tanah konservasi adalah dengan mengembalikan sisa-sisa tanaman setelah panen sebagai sumber bahan organik dalam bentuk mulsa yang mampu menjaga sifat fisik tanah. Disisi lain pengolahan yang intensif dapat merusak struktur dan ruang pori yang telah terbentuk dari bahan organik. Oleh karena itu, pengolahan tanah sebaiknya dilakukan seminimum mungkin. Tujuan penelitian ini adalah untuk mengetahui pengaruh sistem olah tanah dan pemupukan nitrogen jangka panjang terhadap bobot isi, ruang pori total tanah, kekerasan tanah dan produksi tanaman jagung. Percobaan dilakukan dengan menggunakan Rancangan Acak Kelompok (RAK), yang disusun secara faktorial 3 x 2 dengan 4 ulangan. Faktor pertama adalah sistem olah tanah jangka panjang yaitu $\mathrm{T}_{1}=$ Olah Tanah Intensif $(\mathrm{OTI}), \mathrm{T}_{2}=$ Olah Tanah Minimum $(\mathrm{OTM}), \mathrm{T}_{3}=$ Tanpa Olah Tanah $(\mathrm{TOT})$, dan faktor kedua adalah pemupukan nitrogen jangka panjang yaitu $\mathrm{N}_{\mathrm{o}}=0 \mathrm{~kg} \mathrm{~N} \mathrm{ha-1}$, dan $\mathrm{N}_{1}=100 \mathrm{~kg} \mathrm{~N} \mathrm{ha}^{-1}$. Data yang diperoleh diuji homogenitasnya dengan uji Bartlet dan aditivitasnya dengan uji Tukey, kemudian dilakukan analisis ragam. Perbandingan nilai tengah pengamatan diuji dengan menggunakan uji BNT pada taraf 5\%. Hasil penelitian menunjukkan bahwa secara umum bobot isi, ruang pori total tanah, kekerasan tanah dan produksi jagung pada sistem olah tanah intensif tidak berbeda nyata dibandingkan dengan sistem olah tanah konservasi, begitu pula dengan pemupukan nitrogen $100 \mathrm{~kg} \mathrm{~N}$ $\mathrm{ha}^{-1}$ tidak berbeda nyata dibanding dengan tanpa pemupukan $\mathrm{N}$. Tetapi produksi jagung dengan pemupukan $100 \mathrm{~kg} \mathrm{~N} \mathrm{ha}^{-1}$ lebih tinggi dibanding tanpa pemupukan N. Tidak terdapat interaksi antara sistem pengolahan tanah dan pemupukan $\mathrm{N}$ terhadap bobot isi, ruang pori total, kekerasan tanah dan produksi jagung.
\end{abstract}

Kata kunci : jagung, pemupukan nitrogen, sistem olah tanah.

\section{PENDAHULUAN}

Jagung (Zea mays L.) merupakan salah satu tanaman pangan penting selain gandum dan padi. Produktivitas jagung di tingkat nasional dewasa ini mencapai 5,0 ton ha ${ }^{-1}$ (Badan Pusat Statistik Propinsi Lampung, 2013). Penelitian oleh berbagai instansi pemerintah maupun swasta telah menghasilkan teknologi budidaya jagung dengan produktivitas 4,5-10,0 ton ha- ${ }^{-1}$, tergantung pada potensi lahan dan teknologi produksi yang diterapkan (Subandi dkk., 2006).

Lahan kering merupakan salah satu sumberdaya alam yang berpotensi untuk meningkatkan produksi pertanian di Indonesia. Akan tetapi potensi tersebut belum dimanfaatkan secara optimal. Kendala-kendala yang sering ditemui pada lahan kering diantaranya adalah tingkat kesuburan tanah yang rendah, erosi yang tinggi dan kekeringan di musim kemarau (Utomo, dkk., 1993).
Menurut Utomo (1989), Olah tanah konservasi merupakan salah satu pendekatan sistem produksi tanaman yang memperhatikan konservasi lahan. Keuntungan penerapan OTK tersebut antara lain dapat (1) meningkatkan kualitas mulsa in situ, (2) meningkatkan $\mathrm{N}$ dan hara tanah, dan (3) memanfaatkan residu pupuk dari tanaman sebelumnya secara efisien. Cara persiapan lahan yang memenuhi kriteria olah tanah konservasi adalah pengolahan tanah minimum dan tanpa pengolahan tanah (Utomo, 1999). Abdurachman, dkk., (1998) menjelaskan bahwa olah tanah konservasi (OTK) merupakan cara penyiapan lahan yang dapat mengurangi kehilangan tanah dan air kerena erosi dan penguapan dibandingkan dengan cara-cara penyiapan lahan secara konvensional. Hal yang menentukan keberhasilan olah tanah konservasi adalah pemberian bahan organik dalam bentuk mulsa yang cukup (Rachman dkk., 2004). Mulsa dapat menekan pertumbuhan gulma dan mengurangi laju 
pemadatan tanah. Pada sistem olah tanah konservasi, tanah diolah seperlunya atau bila perlu tidak diolah sama sekali, dan mulsa dari residu tanaman sebelumnya dibiarkan menutupi permukaan lahan minimal $30 \%$.

Selain olah tanah konservasi, pemupukan $\mathrm{N}$ juga merupakan cara untuk pengelolaan kesuburan tanah. Pemupukan $\mathrm{N}$ yang dilakukan terus-menerus pada musim tanam sebelumnya dengan sistem olah tanah konservasi memiliki kandungan $\mathrm{N}$ tanah yang lebih tinggi dibandingkan dengan olah tanah intensif (Niswati, dkk., 1994).

Menurut Hakim, dkk. (1986) peranan bahan organik terhadap sifat fisik tanah adalah dapat meningkatkan kemantapan agregat tanah dan memperbaiki struktur tanah. Tanah yang banyak mengandung bahan organik mempunyai humus yang tebal sehingga akan mempunyai sifat fisik yang baik yaitu mempunyai kemampuan menghisap air sampai beberapa kali berat keringnya dan juga memiliki porositas yang tinggi.

Penelitian ini bertujuan untuk (1) mengetahui pengaruh sistem olah tanah terhadap bobot isi, ruang pori total tanah, kekerasan tanah dan produksi tanaman jagung (Zea mays L.), (2) mengetahui pengaruh pemupukan $\mathrm{N}$ terhadap bobot isi, ruang pori total tanah, kekerasan tanah dan produksi tanaman jagung (Zea mays L.), (3) mengetahui pengaruh interaksi antara sistem olah tanah dan pemupukan $\mathrm{N}$ terhadap bobot isi, ruang pori total tanah, kekerasan tanah dan produksi tanaman jagung (Zea mays L.).

\section{BAHAN DAN METODE}

Penelitian ini merupakan penelitian jangka panjang tahun ke-27 dan dilakukan di kebun percobaan POLINELA yang berada pada $105^{\circ} 13^{\prime} 45,5^{\prime \prime}$ $105^{\circ} 13^{\prime} 48,0^{\prime \prime}$ BT dan $05^{\circ} 21^{\prime} 19,6^{\prime \prime}-05^{\circ} 21^{\prime} 19,7^{\prime \prime} \mathrm{LS}$, dengan elevasi $122 \mathrm{~m}$ dari permukaan laut (Utomo, 2012). Penelitian ini dilaksanakan pada bulan Desember 2015 sampai dengan Maret 2016. Analisis contoh tanah dilakukan di Laboratorium Jurusan Ilmu Tanah Fakultas Pertanian Universitas Lampung dan di Laboratorium Analisis POLINELA.

Percobaan ini menggunakan Rancangan Acak Kelompok (RAK) dan disusun secara faktorial $3 \times 2$ dengan 4 ulangan. Sistem olah tanah meliputi tanpa olah tanah (TOT), olah tanah minimum (OTM), olah tanah intensif (OTI); dan pemupukan nitrogen $(\mathrm{N})$ yaitu $0 \mathrm{~kg} \mathrm{~N} \mathrm{ha}^{-1}\left(\mathrm{~N}_{0}\right), 100 \mathrm{~kg} \mathrm{~N}^{-1}\left(\mathrm{~N}_{1}\right)$. Homogenitas ragam diuji dengan uji Bartlet, aditivitas data diuji dengan uji Tukey. Jika asumsi terpenuhi, perbedaan nilai tengah perlakuan diuji dengan uji BNT pada taraf 5\%.
Pada saat dua minggu sebelum tanam, lahan disemprot menggunakan herbisida glifosat dengan dosis 3 - 5 liter ha ${ }^{-1}$, kemudian gulma tersebut digunakan sebagai mulsa untuk perlakuan tanpa olah tanah. Pada petak tanpa olah tanah, lahan tidak diolah sama sekali kecuali lubang tugal untuk penempatan benih, untuk olah tanah minimum lahan cukup dibersihkan dengan cara dikoret, dan serasah gulma dibiarkan menjadi mulsa, (tanah dicangkul sekali sedalam $10 \mathrm{~cm}$ ), sedangkan olah tanah intensif tanah dicangkul dua kali hingga kedalaman $20 \mathrm{~cm}$ dan sisa tanaman gulma dibuang dari petak percobaan. Lahan dibagi menjadi 24 petak percobaan sesuai dengan perlakuan dan dengan ukuran tiap petaknya $4 \mathrm{~m} \times 6 \mathrm{~m}$ dengan jarak antar petak yaitu 1 meter. Jarak tanam yang digunakan $75 \times 25 \mathrm{~cm}$ dan ditanami 1 benih per lubang tanam benih jagung varietas $\mathrm{P}-27$. Pemupukan $\mathrm{P}$ dan $\mathrm{K}$ dilakukan pada $1 \mathrm{MST}$ secara larik. Sedangkan pupuk urea dengan dosis $0 \mathrm{~kg}$ $\mathrm{N} \mathrm{ha}^{-1}$, dan $100 \mathrm{~kg} \mathrm{~N} \mathrm{ha}^{-1}$ diberikan dua kali yaitu sepertiga dosis pada saat jagung berumur 1 MST dan 2/ 3 dosis pada saat jagung memasuki fase vegetatif maksimum yakni 8 MST. Pemeliharaan tanaman dilakukan dengan penyulaman dan penyiangan gulma secara manual. Pengambilan sampel dilakukan yaitu pada plot dengan perlakuan tanpa olah tanah, olah tanah minimum dan olah tanah intensif yang dikombinasikan dengan residu 0 dan $100 \mathrm{~kg} \mathrm{~N} \mathrm{ha}^{-1}$. Pengambilan sampel dilakukan satu kali yaitu setelah panen. Variabel utama yang diamati meliputi bobot isi, ruang pori total, kekerasan tanah dan produksi jagung.

\section{HASIL DAN PEMBAHASAN}

Hasil pengamatan menunjukkan bahwa bobot isi dan ruang pori total pada olah tanah intensif tidak berbeda dari olah tanah konservasi (Tabel 1). Hal ini disebabkan pada sistem olah tanah intensif, tanah yang gembur apabila terjadi hujan mudah tererosi dan terjadi eluviasi sehingga akan menyumbat pori-pori tanah dan tanah akan menjadi lebih padat (bobot isi cenderung meningkat) dan (ruang pori total cenderung rendah). Sedangkan pada sistem tanpa olah tanah dilakukan pemanfaatan gulma dan sisa-sisa tanaman dijadikan mulsa yang berfungsi sebagai penutup tanah atau pelindung tanah dari butirbutir hujan yang jatuh ke tanah. Akibat pemanfaatan gulma dan sisa-sisa tanaman yang dijadikan sebagai mulsa maka kadar bahan organik menjadi tinggi. Ketersediaan bahan organik juga sangat mempengaruhi aktivitas biota tanah pada permukaan tanah sehingga cenderung menurunkan bobot isi dan akan meningkatkan ruang pori total tanah. Bahan organik tanah membantu dalam pembentukan agregat tanah dengan membentuk 
Tabel 1. Pengaruh berbagai sistem pengolahan tanah dan pemupukan $\mathrm{N}$ terhadap bobot isi dan ruang pori total

\begin{tabular}{|c|c|c|c|c|c|}
\hline \multirow[b]{2}{*}{ Sistem olah tanah } & \multirow{2}{*}{$\begin{array}{c}N(\operatorname{kg~N} \\
\left.h^{-1}\right)\end{array}$} & \multicolumn{2}{|c|}{ Bobot isi $\left(\mathrm{g} \mathrm{cm}^{-3}\right)$} & \multicolumn{2}{|c|}{ Ruang pori total (\%) } \\
\hline & & $\begin{array}{c}\text { Kedalaman } \\
0-10 \mathrm{~cm}\end{array}$ & $\begin{array}{c}\text { Kedalaman } \\
10-20 \mathrm{~cm}\end{array}$ & $\begin{array}{c}\text { Kedalaman } \\
0-10 \mathrm{~cm}\end{array}$ & $\begin{array}{c}\text { Kedalaman } \\
10-20 \mathrm{~cm}\end{array}$ \\
\hline \multirow[t]{2}{*}{ Tanpa olah tanah } & 0 & $1,31 \mathrm{a}$ & $1,32 \mathrm{a}$ & $49.80 \mathrm{a}$ & $50,00 \mathrm{a}$ \\
\hline & 100 & $1,37 \mathrm{a}$ & $1,36 \mathrm{a}$ & $47,70 \mathrm{a}$ & $48,80 \mathrm{a}$ \\
\hline \multirow[t]{2}{*}{ Olah tanah minimum } & 0 & $1,41 \mathrm{a}$ & $1,38 \mathrm{a}$ & $46,70 \mathrm{a}$ & $47,90 \mathrm{a}$ \\
\hline & 100 & $1,35 \mathrm{a}$ & $1,36 \mathrm{a}$ & $49,10 \mathrm{a}$ & $48,70 \mathrm{a}$ \\
\hline \multirow[t]{2}{*}{ Olah tanah intens if } & 0 & $1,33 \mathrm{a}$ & $1,35 \mathrm{a}$ & $49,80 \mathrm{a}$ & $48,90 \mathrm{a}$ \\
\hline & 100 & $1,31 \mathrm{a}$ & $1,31 \mathrm{a}$ & $50,50 \mathrm{a}$ & $50,60 \mathrm{a}$ \\
\hline
\end{tabular}

Keterangan: Angka yang diikuti oleh huruf yang sama tidak berbeda nyata dengan uji BNT pada taraf nyata $5 \%$.

granul-granul dan memperbesar volume dan pori-pori tanah yang ada, sehingga ruang pori total tanah meningkat. Akibatnya, bobot isi dan ruang pori total pada kedua sistem olah tanah menjadi tidak berbeda. Selain itu, diduga serasah yang diberikan pada OTK terlalu sedikit yaitu hanya mencapai 6-8 tha $^{-1}$ sehingga rongga dan agregat tanah yang terbentuk belum cukup untuk menurunkan bobot isi dan belum mampu untuk meningkatkan agregasi tanah. Kohnke (1968) menyatakan bahwa semakin tinggi jumlah serasah atau mulsa dan residu pemupukan $\mathrm{N}$ yang diberikan kedalam tanah mengakibatkan populasi organisme tanah meningkat. Dengan meningkatnya populasi organisme tanah, maka aktivitas biota tanah semakin banyak dan mengakibatkan rongga atau pori tanah yang terbentuk meningkat (Asdak, 2002).

Tabel 1 juga menunjukkan bahwa pada perlakuan pemupukan nitrogen yang diberikan belum mampu mempengaruhi agregasi tanah sehingga belum mempengaruhi bobot isi dan ruang pori total tanah. Di duga, penambahan biomassa sebagai akibat dari pemupukan $\mathrm{N}$ tidak begitu banyak, sehingga serasah yang dihasilkan juga sedikit. Artinya tambahan bahan organik tanah akibat dari dekomposisi serasah sedikit sehingga tidak berbeda dengan perlakuan tanpa N. Sedangkan pada sistem olah tanah konservasi peningkatan penambahan bahan organik tanah relatif lebih tinggi dari $\mathrm{N}$, sehingga peluang penambahan bahan organik menjadi lebih tinggi. Temuan ini sesuai dengan pendapat Arsyad (2010), yang mengatakan bahwa pengaruh pengolahan tanah hanya bersifat sementara menggemburkan tanah, selanjutnya akan terjadi erosi dan penyumbatan pori-pori tanah akibat pengolahan tanah yang salah. Pada olah tanah minimum, nilai bobot isi dan ruang pori total tidak berbeda jika dibandingkan dengan olah tanah intensif maupun tanpa olah tanah. Hal ini disebabkan karena tanah hanya diolah seperlunya saja sehingga masih terdapat bongkah-bongkahan tanah yang cukup besar, sehingga tanah tidak mudah hancur.

Bobot isi merupakan parameter yang dapat digunakan untuk menilai kepadatan suatu tanah. Semakin kecil bobot isi tanah maka semakin gembur tanah tersebut, sebaliknya semakin besar bobot isi semakin padat tanah tersebut. Pemberian $\mathrm{N}$ dan serasah atau mulsa pada perlakuan olah tanah konservasi sebagai penutup tanah diharapkan dapat mengurangi erosi dan aliran permukaan, serta memperbaiki sifat fisik tanah. Foth (1978) dalam penelitiannya menyatakan bahwa bobot isi $1,0 \mathrm{~g} \mathrm{~cm}^{-3}$, bagus untuk perkembangan akar tanaman dalam menembus tanah karena tidak terjadi pemadatan. Nilai ruang pori total juga sejalan dengan nilai bobot isi tanah. Pada tanah yang ruang pori totalnya tinggi memiliki bobot isi yang rendah, demikian juga sebaliknya. Hal ini sesuai dengan pendapat Soepardi (1983) bahwa, bobot isi tanah berbanding terbalik dengan ruang pori total dan sangat ditentukan olah bahan organik yang terkandung didalam tanah.

Untuk menurunkan bobot isi tanah diperlukan mulsa sisa tanaman yang banyak dan memerlukan waktu lebih dari satu musim tanam. Hal ini sesuai dengan pendapat Brown dan Dicky (1970) yang menyatakan bahwa untuk menurunkan bobot isi tanah, meningkatkan permeabilitas, porositas, dan ruang pori total diperlukan mulsa sisa tanaman lebih dari 11 ton ha ${ }^{-1}$.

Seperti halnya bobot isi, hasil penelitian menunjukkan bahwa sistem olah tanah intensif dan residu pemupukan nitrogen $\left(100 \mathrm{~kg} \mathrm{~N} \mathrm{ha}^{-1}\right)$ tidak berpengaruh nyata terhadap berbagai taraf kekerasan tanah. Diduga serasah yang diberikan pada sistem olah tanah konservasi terlalu sedikit yaitu hanya mencapai 6-8 ton 
ha $^{-1}$ sehingga bahan organik tanah yang dihasilkan yang mempengaruhi ketahanan agregat tanah yang terbentuk belum cukup untuk menghasilkan penurunan kekerasan tanah.

Kekerasan yang terjadi dipengaruhi oleh kondisi ketersediaan bahan organik dan porositas tanah yang ada di lahan tersebut. Bahan organik berperan dalam menciptakan kegemburan tanah. Pemberian bahan organik akan mempengaruhi terciptanya peningkatan porositas tanah yang tinggi. Sehingga kekerasan tanah dapat diatasi.

Pada sistem olah tanah intensif pemanfaatan sisasisa tanaman dan gulma sebagai penutup lahan dan bahan organik tidak dilakukan. Penghancuran agregat tanah pun terjadi pada pengolahan tanah intensif ini sehingga akan menimbulkan dispersi agregat dan merusak struktur tanah. Hal-hal tersebut akan menyebabkan kekerasan tanah menjadi tinggi terutama pada lapisan bawah. Sedangkan pada sistem olah tanah konservasi, dengan adanya pemanfaatan sisa-sisa tanaman dan gulma sebagai penutup lahan, dan tidak dilakukanya penghancuran agregat tanah maka tahanan penetrasi tanah di lahan olah tanah konservasi tidak tinggi. Sehingga kekerasan tanah pada kedua sistem olah tanah, baik olah tanah konservasi dan olah tanah intensif menjadi tidak berbeda.

Hasil penelitian jangka panjang yang dilakukan sejak 1987 menunjukkan pola kekerasan tanah seperti pada (Gambar 1a). Pada permukaan tanah 0-2,5 cm, kekerasan tanah TOT setelah 27 tahun cenderung lebih tinggi dari pada OTI. Akan tetapi sebaliknya pada kedalaman $10 \mathrm{~cm}$, justru kekerasan tanah OTI lebih tinggi dari pada TOT. Pada kedalaman lebih dari $25 \mathrm{~cm}$ kekerasan tanah pada ketiga olah tanah sama-sama meningkat dan tidak dapat dideteksi oleh penetrometer.
Kekerasan tanah berhubungan erat dengan bobot isi, ruang pori total, dan kandungan bahan organik tanah. Semakin tinggi kandungan bahan organik maka semakin rendah bobot isi tanah, sehingga kekerasan tanah berkurang. Hal ini sesuai dengan pendapat Sarief (1989), bahwa penurunan kekerasan tanah diikuti menurunnya bobot isi tanah dan meningkatnya ruang pori total tanah. Sebaliknya peningkatan kekerasan tanah akan meningkatkan bobot isi tanah, menurunkan pori aerase dan menurunkan permeabilitas tanah. Kontribusi penerapan sistem olah tanah konservasi dan olah tanah intensif dengan pemberian pemupukan nitrogen tidak berbeda terhadap penurunan kekerasan dan kepadatan tanah.

Hal ini disebabkan karena sistem tanpa olah tanah mampu menciptakan kondisi struktur tanah yang baik tidak mudah hancur oleh tumbukan butir-butir hujan sehingga permeabilitas tanah dapat ditingkatkan. Dengan meningkatnya populasi organisme tanah, maka aktivitas biota tanah semakin banyak dan mengakibatkan rongga atau pori tanah yang terbentuk meningkat (Asdak, 2002).

Beberapa hasil penelitian menunjukkan batasan kepadatan dan kekerasan tanah, dimana tanah sudah memerlukan pengolahan. Kekerasan tanah ditentukan dari ketahanan tanah terhadap penetrasi penetrometer. Menurut Suwardjo (1981), berdasarkan hasil penelitiannya menyimpulkan bahwa bila kekerasan tanah telah mencapai $1.5 \mathrm{MPa}$ atau $\left(15 \mathrm{kgf} \mathrm{cm}^{-2}\right)$, maka sudah diperlukan pengolahan. Menurut Mazurak dan Pohlman (1968), pengaruh ketahanan penetrasi tanah terhadap perkembangan akar kacang hijau dan jagung, perkembangan akarnya akan sangat terhambat pada ketahanan penetrasi $1 \mathrm{MPa}\left(10 \mathrm{kgf} \mathrm{cm}^{-2}\right)$ atau bobot isi $1.6 \mathrm{~g} \mathrm{cc}^{-3}$, diatas $1 \mathrm{Mpa}$ akar kacang hijau dan jagung hampir tidak ditemukan. Menurut Utomo (1995), bobot
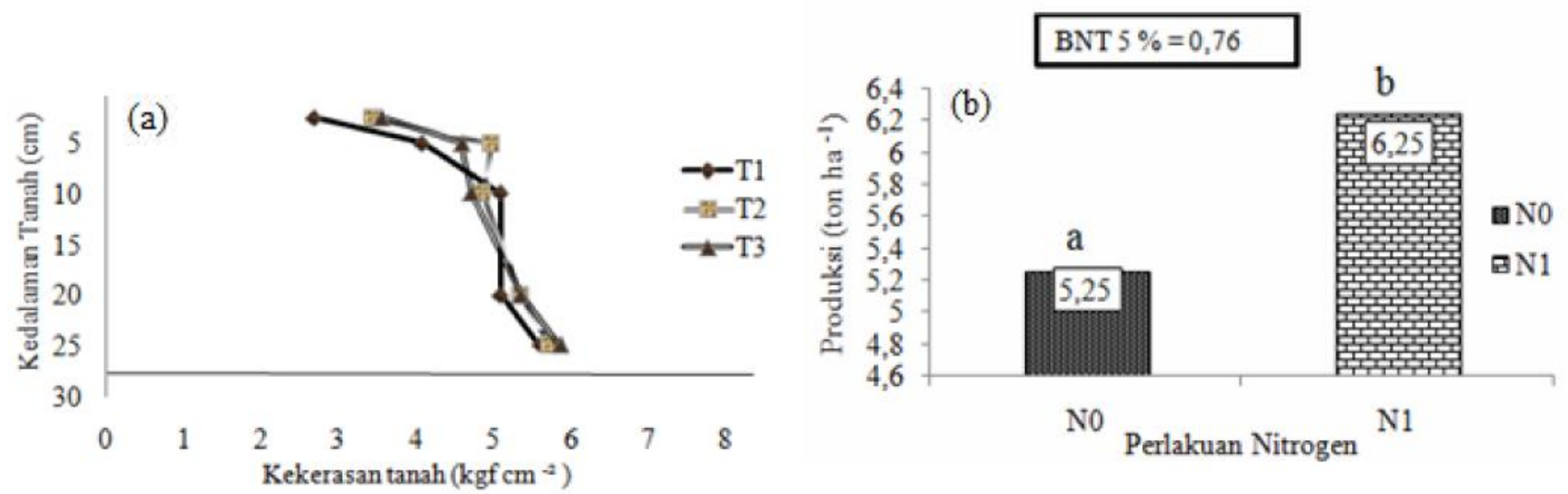

Gambar 1. (a) Kekerasan tanah dan (b) produksi jagung (ton ha ${ }^{-1}$ ) pada berbagai sistem pengolahan tanah dan pemberian residu pemupukan nitrogen. $\mathrm{T} 1=$ tanpa olah tanah; $\mathrm{T} 2=$ olah tanah minimum; $\mathrm{T} 3=$ olah tanah intensif; $\mathrm{N}_{0}=$ tanpa residu pupuk ; $\mathrm{N}_{1}=$ residu pupuk $100 \mathrm{~kg} \mathrm{~N} \mathrm{ha}^{-1}$. 
isi yang tinggi menghasilkan tanah yang lebih kompak dan sulit ditembusi oleh akar tanaman.

Hasil analisis ragam menunjukkan bahwa pemupukan nitrogen berpengaruh nyata terhadap produksi jagung, sedangkan sistem olah tanah dengan interaksinya dengan pemupukan nitrogen tidak berpengaruh nyata. Pemupukan nitrogen berpengaruh terhadap produksi (Gambar 1b) disebabkan nitrogen mengandung unsur makro yang esensial bagi tanaman. Hal ini disebabkan karena pemupukan nitrogen merupakan salah satu unsur hara makro yang diperlukan bagi pertumbuhan tanaman sehingga kebutuhan unsur hara bagi tanaman dapat terpenuhi. Menurut pendapat Warisno (1998), persediaan unsur hara yang cukup pada setiap fase pertumbuhan merupakan persyaratan utama untuk mendapatkan pertumbuhan dan hasil yang optimum. Menurut Minardi (2000) bahwa pemberian NPK dapat memberikan tambahan unsur NPK tersedia dalam tanah yang berpengaruh pada pertumbuhan tanaman. Hal ini didukung Damanik (2007) yang menyatakan nitrogen di dalam tanaman sangat penting untuk pembentukan protein, daun-daunan dan berbagai senyawa organik lainnya nitrogen adalah unsur hara yang paling banyak dibutuhkan tanaman dan mempunyai peranan yang sangat penting untuk pertumbuhaan tanaman.

Sedangkan sistem olah tanah tidak berpengaruh nyata terhadap produksi jagung. Hal ini karena olah tanah konservasi dilakukan pemanfaatan gulma dan sisasisa tanaman sebagai mulsa, tetapi tanahnya sudah makin memadat, sehingga berpengaruh terhadap produksi jagung. Sementara pada olah tanah intensif tidak dilakukan pemanfaatan gulma dan sisa-sisa tanaman sebagai mulsa, sehingga apabila terjadi hujan akan mudah terjadi erosi dan terjadi eluviasi partikelpartikel tanah sehingga akan menyumbat pori-pori tanah dan tanah akan menjadi lebih padat (bobot isi cenderung meningkat). Hal ini menyebabkan kedua sistem olah tanah tidak berpengaruh terhadap produksi jagung.

\section{KESIMPULAN}

Berdasarkan hasil penelitian jangka panjang ini, maka dapat disimpulkan bahwa bobot isi, ruang pori total, kekerasan tanah dan produksi jagung pada sistem olah tanah intensif tidak berbeda nyata dibandingkan dengan sistem olah tanah konservasi. Bobot isi, ruang pori total, dan kekerasan tanah pada pemupukan $100 \mathrm{~kg} \mathrm{~N} \mathrm{ha}^{-1}$ tidak berbeda nyata dibanding dengan tanpa pemupukan $\mathrm{N}$. Tetapi produksi jagung pada pemupukan $100 \mathrm{~kg} \mathrm{~N}$ ha $^{-1}$ lebih tinggi dibanding tanpa pemupukan N. Tidak terdapat interaksi antara sistem pengolahan tanah dan pemupukan $\mathrm{N}$ terhadap bobot isi, ruang pori total, kekerasan tanah dan produksi.

\section{DAFTAR PUSTAKA}

Adri dan Endrizal. 2009. Prospek dan Strategi Pengembangan Jagung Varietas Sukmaraga di Prov. Jambi. Prosiding Seminar Nasional Serealia.

Afandi. 2005. Penuntun Praktikum Fisika Tanah. Universitas Lampung. Bandar Lampung.

Badan Pusat Statistik Propinsi Lampung. 2013. Luas Panen dan Produksi dan Produktivitas Tanaman Jagung, Lampung.

Damanik P. 2007. Perubahan Kepadatan Tanah dan Produksi Tanaman Kacang Tanah Akibat Intensitas Lintasan Traktor dan Dosis Bokasi. Bogor: Fakultas Teknologi Pertanian, Institut Pertanian Bogor.

Ditjen Bina Produksi Tanaman Pangan. 2013. Tanaman Pangan. Jakarta.

Gill, W. R., and G. E. Vanden Berg. 1967. Soil Dynamics in Tillage and Traction. USDA Agric. Handb. N. 316. U.S. Government Printing Office, Washington, DC.

Hakim, N., Nyapka, A.M. Lubis, S.G. Nugroho, R. Saul, A. Diha, G.B.Hong, dan H.H Bailey. 1986. Dasar-Dasar Ilmu Tanah. Universitas Lampung. Bandar Lampung. $448 \mathrm{hlm}$.

Istiana, Heri. 2007. Cara Aplikasi Pupuk Nitrogen dan Pengaruhnya pada Tanaman Tembakau Madura. Buletin Teknik Pertanian Vol. 12 No. $2,2007$.

Lal, R. and D.J.Greenland. 1979. Soil Physical Properties and Crop Production in the Humid Tropic. John Willey \& Sons. Chichester New York, Brisbane

Niswati, A., M. Utomo, dan S.G. Nugroho. 1994. Dampak Mikrobiologi Tanah Penerapan Teknik Tanpa Olah Tanah dengan Herbisida Amino Glifosfat Secara Terus-menerus pada Lahan Kering di Lampung. Laporan Penelitian DP3M. Unila.

Rachman, B. 2003. Perdagangan Internasional Komoditas Jagung dalam Kasryno et al. (Eds). Ekonomi Jagung Indonesia. Badan Litbang Pertanian. Jakarta 
Simatupang, P., Marwoto, dan Dewa K.S. Swastika. 2005. Lokakarya Pengembangan Kedelai di Lahan sub Optimal di BALITKABI Malang.

Tate, R. L. 1987. Soil Organic Matter: Biological and Ecological Effects. Wiley/ Interscience, New York, NY, USA

Utomo, M. 1989. Olah Tanah Konservasi, Teknologi Pertanian Lahan Kering. Pidato Ilmiah Dies natalies Universitas Lampung ke-24. 23 September 1989. Universitas Lampung.

Utomo, M. 1990. Budidaya Pertanian Tanpa Olah Tanah,Teknologi untuk Pertanian Berkelanjutan. Direktorat Produksi Padi dan palawija. Departemen Pertanian RI. Jakarta.

Utomo, M. 1991. Budiddaya Pertanian Tanpa Olah Tanah Teknologi Untuk Pertanian Berkelanjutan. Universitas Lampung. $22 \mathrm{hlm}$.

Utomo, M. 1995a. Kekerasan Tanah dan Serapan Hara Tanaman Jagung Pada Olah Tanah Konservasi Jangka Panjang. J. Tanah Tropika. 1 1-7.
Utomo, M.1995b. Sistem Olah Tanah Konservasi dan Pertanian Berkelanjutan. Sarasehan tentang Kebijakan Pertanian Berkelanjutan. Jakarta. 9 Maret 1995.

Utomo, M. 1997. Olah Tanah Konservasi Teknologi Pengolahan Lahan Kering Berkelanjutan. Pidato Pengukuhan Guru Besar Ilmu Pengolahan Tanah Fakultas Pertanian Universitas Lampung. 22 September 1997. (26 hlm).

Utomo, M. 2004. Olah Tanah Konservasi untuk Budidaya Jagung Berkelanjutan. Prosiding Seminar Nasional IX Budidaya Pertanian Olah Tanah Konservasi. Gorontalo.

Utomo, M. 2012. Tanpa Olah Tanah: Teknologi Pengelolaan Pertanian Lahan Kering. Lembaga Penelitian Universitas Lampung. Bandar Lampung. $110 \mathrm{hlm}$. 